\title{
Rapid Labeling of Metabolically Engineered Cell-Surface Glycoconjugates with a Carbamate-Linked Cyclopropene Reporter
}

\author{
Anne-Katrin Späte, Holger Bußkamp, Andrea Niederwieser, Verena F. Schart, Andreas Marx, \\ and Valentin Wittmann* \\ University of Konstanz, Department of Chemistry and Konstanz Research School Chemical Biology (KoRS CB), Universitätsstraße \\ 10, 78457 Konstanz, Germany
}

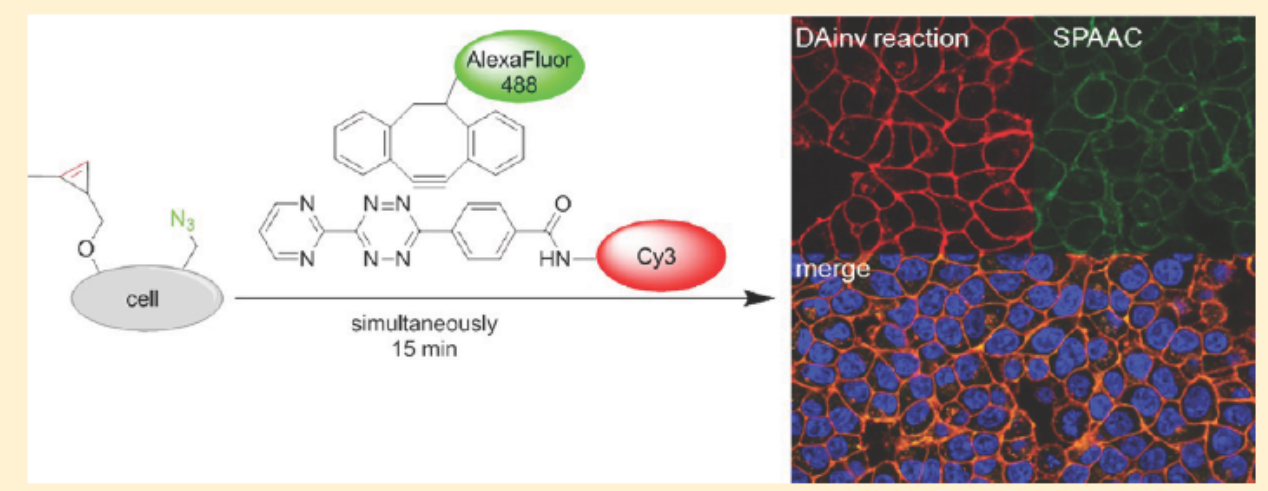

ABSTRACT: Metabolic oligosaccharide engineering is a valuable tool to monitor cellular carbohydrates. Here, we report the synthesis of a novel $N$ acyl mannosamine derivative bearing a methylcyclopropene tag that is attached to the sugar via a carbamate moiety. This derivative undergoes rapid Diels-Alder reaction with inverse electron demand. We demonstrate that the cell's biosynthetic machinery incorporates this non natural mannosamine derivative into glycoconjugates that can, subsequently, be labeled within less than $10 \mathrm{~min}$ with a new sulfo $\mathrm{Cy} 3-$ tetrazine conjugate. Using this tetrazine dye conjugate for the detection of the methylcyclopropene tagged mannosamine derivative, we could achieve dual labeling of two different metabolically incorporated sugars combining a Diels-Alder reaction with inverse electron demand and a strain promoted azide-alkyne cycloaddition which are carried out simultaneously in a single step.

\section{INTRODUCTION}

The development of metabolic oligosaccharide engineering (MOE) as an important tool to visualize glycoconjugates in vitro and in vivo has significantly advanced glycobiology research during the past decade. ${ }^{1-3}$ In this approach, cells are grown in the presence of non natural monosaccharides that contain a functional group with a unique reactivity (a chemical reporter), but are nevertheless accepted by the cell's biosynthetic machinery. For instance, non natural $N$ acetyl D mannosamine (ManNAc) analogues can be fed to cells and are incorporated into membrane sialoglycoconjugates. ${ }^{4}$ After successful incorpo ration of the modified sugar into the glycoconjugate, different ligation reactions $s^{5,6}$ can be performed with the reporter group to label the glycan. Well established ligation reactions in this context are the ketone hydrazide ligation, ${ }^{7}$ Staudinger ligation, ${ }^{8}$ and azide-alkyne $[3+2]$ cycloaddition (copper catalyzed,10 or strain promoted, ${ }^{11,12}$ often referred to as click reaction). The Diels-Alder reaction with inverse electron demand (DAinv reaction) has also proven to be a valuable ligation reaction ${ }^{13-18}$ that can be orthogonal to azide-alkyne cycloaddition, ${ }^{19,20}$ a feature that allows dual labeling of two sugars within one MOE experiment. $^{21-23}$ Dienophiles for a DAinv reaction that have been reacted with $1,2,4,5$ tetrazines ${ }^{24}$ and successfully employed in MOE are terminal alkenes $1,^{21}$ isonitriles $2,23,25$ and cyclopropenes $3^{22,26}$ (Chart 1).

Terminal alkenes 1 are small and undergo DAinv reaction with tetrazines of type 4 with second order rate constants of up to $k=$ $0.04 \mathrm{M}^{-1} \mathrm{~s}^{-1}$. ${ }^{21}$ The reaction rate of isonitriles 2 with tetrazines of type 5 is higher (up to $k=0.57 \mathrm{M}^{-1} \mathrm{~s}^{-1}$ ), but not all isonitriles lead to stable ligation products after the DAinv reaction. ${ }^{27} \mathrm{MOE}$ was also performed using strained cyclopropenes 3 that are small enough to be accepted by cellular enzymes. ${ }^{22,26}$ The Devaraj group determined a second order rate constant of $k=0.137 \mathrm{M}^{-1}$ $\mathrm{s}^{-1}$ for the reaction of 3 with tetrazines of type 6 at $37^{\circ} \mathrm{C}^{28}$ They also reported that methylcyclopropene carbamate 7 reacts 100 fold faster $\left(k=13 \mathrm{M}^{-1} \mathrm{~s}^{-1}\right)$. However, 7 has so far not been used for MOE. Both cyclopropenes of types 3 and 7 have been shown to be stable in aqueous solution in the presence of biological nucleophiles. ${ }^{26,28}$ 
Chart 1. Dienophiles and 1,2,4,5 Tetrazines for DAinv Reactions<smiles>[R]NC(=O)CCC=C</smiles><smiles>[R]NC(=O)CC[N+]#[C-]</smiles><smiles>[R]NC(=O)C1=CC1C</smiles><smiles>[R]NC(=O)c1ccc(-c2nnc(-c3ncccn3)nn2)cc1</smiles><smiles>[R]NC(=O)c1ccc(-c2nnc(-c3ccccn3)nn2)nc1</smiles>
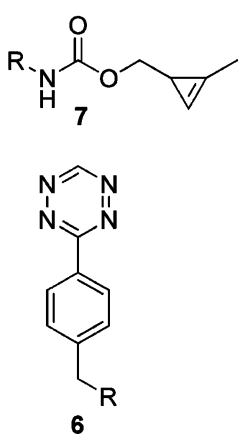

We and others could recently demonstrate that ManNAc analogues bearing a carbamate moiety are accepted by the cell's biosynthetic machinery. ${ }^{21,29}$ Combining that knowledge with the fact that methylcyclopropene carbamates 7 react significantly faster than the corresponding amides 3 , we hypothesized that a methylcyclopropene attached to the sugar via a carbamate is metabolized, offering the option of rapid sugar labeling by a DAinv reaction. Here we report the synthesis of a novel $N$ acyl mannosamine derivative that bears such a tag and reacts instantly with tetrazines, as well as its application in MOE. For dual labeling of cells two different sugars (one azide labeled, one methylcyclopropene carbamate labeled) were metabolically incorporated. Incubation with a mixture of an AlexaFluor488 labeled dibenzocyclooctyne (DIBO 488) and a novel sulfo Cy3 labeled tetrazine $(\mathrm{Tz} \mathrm{Cy} 3)$ allowed dual labeling within minutes in a single step.

\section{EXPERIMENTAL SECTION}

General Methods. All chemicals were purchased from Aldrich, Fluka, and Dextra and used without further purification. AlexaFluor647 labeled streptavidin, AlexaFluor488 DIBO, and Hoechst 33342 were purchased from Invitrogen. Technical solvents were distilled prior to use. All reactions were carried out in dry solvents, purchased from Aldrich. All reactions were monitored by TLC on silica gel 60 F254 (Merck) with detection by UV light $(\lambda=254 \mathrm{~nm})$. Additionally, acidic ethanolic $p$ anisaldehyde solution followed by gentle heating was used for visualization. Preparative flash column chromatography (FC) was performed with an MPLC Reveleris system from Grace. Nuclear magnetic resonance (NMR) spectra were recorded at room temperature on Avance III 400 and Avance III 600 instruments from Bruker. Chemical shifts are reported relative to solvent signals $\left(\mathrm{CDCl}_{3}: \delta_{\mathrm{H}}=7.26 \mathrm{ppm}, \delta_{\mathrm{C}}=77.16 \mathrm{ppm}\right)$. Signals were assigned by first order analysis and, when feasible, assignments were supported by two dimensional ${ }^{1} \mathrm{H},{ }^{1} \mathrm{H}$ and ${ }^{1} \mathrm{H},{ }^{13} \mathrm{C}$ correlation spectroscopy (COSY, HMBC, and HSQC). ESI MS spectra were recorded on an Esquire 3000 plus instrument from Bruker Daltonics. High resolution ESI TOF mass spectra were recorded on a micrOTOF II instrument from Bruker. LC MS analyses were conducted on a LCMS2020 instrument from Shimadzu (pumps LC $20 \mathrm{AD}$, autosampler SIL 20AT HAT, column oven CTO 20AC, UV-vis detector SPD 20A, controller CBM 20, ESI detector, and software LCMS

solution) with an EC 125/4 Nucleodur C18, $3 \mu \mathrm{M}$ column (Machery Nagel). A binary gradient of acetonitrile (with $0.1 \%$ formic acid) in water (with $0.1 \%$ formic acid) was used at a flow rate of $0.4 \mathrm{~mL} \mathrm{~min}^{-1}$. Semipreparative high performance liquid chromatography (HPLC) was conducted on a LC 20A prominence system (pumps LC 20AT, auto sampler SIL 20A, column oven CTO 20AC, diode array detector SPD M20A, ELSD LT II detector, controller CBM 20A, and software LC solution) from Shimadzu. For reversed phase HPLC an Eurospher 100 C18 column from Knauer $(16 \times 250$ mm, flow $8 \mathrm{~mL} \mathrm{m^{-1 }}$ ) was used as stationary phase and a gradient of acetonitrile in water with $0.1 \%$ formic acid was used as mobile phase. UV-vis absorption was measured using a Carry 50 instrument from Varian and software scanning kinetics. Microscopy was performed using a point laser scanning confocal microscope (Zeiss LSM 510 Meta) equipped with Meta detector for spectral imaging.

Activated Cyclopropene 11. (2 Methyl 3 (trimethylsilyl) cycloprop 2 en $1 \mathrm{yl}$ )methanol $8^{26,28}(200 \mathrm{mg}, 1.2 \mathrm{mmol})$ was dissolved in THF $(6 \mathrm{~mL})$ under nitrogen, treated with $\mathrm{Bu}_{4} \mathrm{NF}$ in THF (1.4 M solution, $1 \mathrm{~mL}$ ), and stirred at room temperature for $2 \mathrm{~h}$. The reaction mixture was cooled to $4{ }^{\circ} \mathrm{C}$ and pyridine (5 $\mathrm{mL})$ and $p$ nitrophenyl chloroformate $10(700 \mathrm{mg}, 3.2 \mathrm{mmol})$ were added. The reaction mixture was stirred and allowed to warm to room temperature overnight. The reaction mixture was concentrated and purified by FC (silica, $0-5 \%$ ethyl acetate in petroleum ether) to yield 11 as a colorless oil $(250 \mathrm{mg}, 83 \%) .{ }^{1} \mathrm{H}$ $\operatorname{NMR}\left(400 \mathrm{MHz}, \mathrm{CDCl}_{3}\right): \delta(\mathrm{ppm})=8.35-8.19\left(\mathrm{~m}, 2 \mathrm{H}, \mathrm{H}_{\mathrm{ar}}\right)$, $7.46-7.32\left(\mathrm{~m}, 2 \mathrm{H}, \mathrm{H}_{\mathrm{ar}}\right), 6.61(\mathrm{t}, J=1.4 \mathrm{~Hz}, 1 \mathrm{H},=\mathrm{CH}), 4.26-$ $4.02\left(\mathrm{~m}, 1 \mathrm{H}, \mathrm{CH}_{2}\right), 2.17\left(\mathrm{~d}, J=1.2 \mathrm{~Hz}, 3 \mathrm{H}, \mathrm{CH}_{3}\right), 1.77(\mathrm{td}, J=$ 5.3, $\left.1.6 \mathrm{~Hz}, 1 \mathrm{H}, \mathrm{CH}_{2} \mathrm{CH}\right) ;{ }^{13} \mathrm{C}$ NMR $\left(101 \mathrm{MHz}, \mathrm{CDCl}_{3}\right): \delta$ $(\mathrm{ppm})=155.92\left(\mathrm{C}_{\text {quart }}\right), 152.81\left(\mathrm{C}_{\text {quart }}\right), 145.44\left(\mathrm{C}_{\text {quart }}\right), 125.42$ $\left(\mathrm{C}_{\mathrm{ar}} \mathrm{H}\right), 121.95\left(\mathrm{C}_{\mathrm{ar}} \mathrm{H}\right), 120.32\left(\mathrm{C}_{\text {quart }}\right), 101.83(=\mathrm{CH}), 77.53$ $\left(\mathrm{CH}_{2}\right), 16.79\left(\mathrm{CH}_{3}\right), 11.80\left(\mathrm{CH}_{2} \mathrm{CH}\right)$.

$\mathrm{AC}_{4}$ ManNCyoc (13). To a solution of mannosamine hydrochloride (12) (1 g, $4.6 \mathrm{mmol})$ in $\mathrm{MeOH}(10 \mathrm{~mL})$ was added $\mathrm{NaOMe}(0.5 \mathrm{M}$ in $\mathrm{MeOH})(9 \mathrm{~mL}, 4.6 \mathrm{mmol})$ under nitrogen. After stirring for $90 \mathrm{~min}$ at room temperature, the solution was added to activated cyclopropene 11 (1 g, $4.8 \mathrm{mmol})$. After stirring for $48 \mathrm{~h}$ at room temperature the solvent was evaporated under reduced pressure. The residue was dissolved in pyridine $(10 \mathrm{~mL})$ and acetic anhydride $(5 \mathrm{~mL})$ was added. After stirring for $24 \mathrm{~h}$ at room temperature, the solvents were evaporated under reduced pressure. The residue was dissolved in $\mathrm{CH}_{2} \mathrm{Cl}_{2}(125 \mathrm{~mL})$, washed with $10 \%$ aq. $\mathrm{KHSO}_{4}(100 \mathrm{~mL})$, sat. aq. $\mathrm{NaHCO}_{3}(100 \mathrm{~mL})$, and brine $(100 \mathrm{~mL})$. The organic layer was dried $\left(\mathrm{MgSO}_{4}\right)$ and the solvent was evaporated under reduced pressure. The residue was purified by FC (silica, $0-7 \%$ ethyl acetate in petroleum ether) to afford $\mathrm{Ac}_{4} \mathrm{ManNCyoc} 13$ together with its $\beta$ anomer. Further purification by HPLC allowed separation of the $\alpha$ anomer 13 (200 mg, 10\%). ${ }^{1} \mathrm{H}$ NMR $\left(400 \mathrm{MHz}, \mathrm{CDCl}_{3}\right): \delta(\mathrm{ppm})=6.58(\mathrm{~s}, 1 \mathrm{H},=\mathrm{CH}), 6.09(\mathrm{~d}, J=$ $1.2 \mathrm{~Hz}, 1 \mathrm{H}, \mathrm{H} 1), 5.31(\mathrm{dd}, J=10.2,4.3 \mathrm{~Hz}, 1 \mathrm{H}, \mathrm{H} 3), 5.20(\mathrm{t}, J=$ $10.0 \mathrm{~Hz}, 1 \mathrm{H}, \mathrm{H} 4), 5.02$ (d, $J=9.3 \mathrm{~Hz}, 1 \mathrm{H}, \mathrm{NH}), 4.34$ (ddd, $J=$ 9.2, 4.2, $1.2 \mathrm{~Hz}, 1 \mathrm{H}, \mathrm{H} 2$ ), 4.26 (dd, $J=12.2,4.3 \mathrm{~Hz}, 1 \mathrm{H}, \mathrm{H} 6 \mathrm{a}$ ), 4.11-3.99 (m, 2H, H 6b, H5), 3.95 (d, $J=5.1 \mathrm{~Hz}, 2 \mathrm{H}, \mathrm{CH}_{2}$ ), 2.17 (s, 3H, OAc), 2.14 (s, 3H, $\left.\mathrm{CH}_{3}\right), 2.11$ (s, 3H, OAc), 2.06 (s, $3 \mathrm{H}, \mathrm{OAc}), 2.02$ (s, 3H, OAc), $1.69-1.64\left(\mathrm{~m}, 1 \mathrm{H}, \mathrm{CH}_{2} \mathrm{CH}\right) ;{ }^{13} \mathrm{C}$ $\operatorname{NMR}\left(151 \mathrm{MHz}, \mathrm{CDCl}_{3}\right) \delta(\mathrm{ppm})=170.75\left(\mathrm{C}_{\text {quart }}\right), 170.23$ $\left(\mathrm{C}_{\text {quart }}\right), 169.74\left(\mathrm{C}_{\text {quart }}\right), 168.29\left(\mathrm{C}_{\text {quart }}\right), 156.41\left(\mathrm{C}_{\text {quart }}\right), 120.56$ $\left(\mathrm{C}_{\text {quart }}\right), 102.39(=\mathrm{CH}), 92.12(\mathrm{C} 1), 73.48\left(\mathrm{CH}_{2}\right), 70.33(\mathrm{C} 5)$, 69.31 (C 3), 65.52 (C 4), 62.10 (C 6), 51.25 (C 2), 21.03 $\left(\mathrm{C}_{\text {quart }}\right), 20.90\left(\mathrm{C}_{\text {quart }}\right), 20.78\left(\mathrm{C}_{\text {quart }}\right), 17.20\left(\mathrm{CH}_{2} \mathrm{CH}\right), 11.80$ 
$\left(\mathrm{C}_{\text {quart }}\right)$; ESI MS: $m / z$ calcd. for $\mathrm{C}_{20} \mathrm{H}_{27} \mathrm{NO}_{11}: 480.15[M+\mathrm{Na}]^{+}$, found: 480.00 .

Cy3-amido-hexylamine 20. The triethylammonium salt of Cy3 NHS 18 (220 mg, $0.26 \mathrm{mmol}$ ) was dissolved in dry DMF (4 $\mathrm{mL})$. $\operatorname{EtN}(i \operatorname{Pr})_{2}(73 \mu \mathrm{L}, 0.42 \mathrm{mmol})$ and $N$ Boc hexylenedi amine ( $94 \mu \mathrm{L}, 0.42 \mathrm{mmol})$ were added. The solution was stirred overnight at room temperature. Ethyl acetate $(20 \mathrm{~mL})$ was added to the solution to precipitate $\mathrm{Cy} 3$ conjugate 19 . The product was collected by centrifugation, washed with additional $20 \mathrm{~mL}$ of ethyl acetate, and purified by RP HPLC. Without further analysis, 19 was dissolved in DMF $(2 \mathrm{~mL})$ and trifluoroacetic acid $(2 \mathrm{~mL})$ was added. The solution was stirred for $5 \mathrm{~h}$ at room temperature and then concentrated under reduced pressure to remove the volatile acid. Ethyl acetate $(20 \mathrm{~mL})$ was added to precipitate the product which was collected by centrifugation and washed with additional $20 \mathrm{~mL}$ of ethyl acetate. The precipitate was dissolved in water $(9 \mathrm{~mL})$ and purified by RP HPLC to give $20(67 \mathrm{mg}, 30 \%)$ as a magenta oil. ${ }^{1} \mathrm{H} \mathrm{NMR}\left(400 \mathrm{MHz}, \mathrm{D}_{2} \mathrm{O}\right): \delta$ $(\mathrm{ppm})=8.52(\mathrm{t}, J=13.5 \mathrm{~Hz}, 1 \mathrm{H}), 7.96-7.82(\mathrm{~m}, 4 \mathrm{H}), 7.42-$ $7.33(\mathrm{~m}, 2 \mathrm{H}), 6.40(\mathrm{dd}, J=13.3 \mathrm{~Hz}, 4.2 \mathrm{~Hz}, 2 \mathrm{H}), 4.20-4.07(\mathrm{~m}$, $4 \mathrm{H}), 3.00-2.90(\mathrm{~m}, 4 \mathrm{H}), 2.20(\mathrm{t}, J=6.9 \mathrm{~Hz}, 2 \mathrm{H}), 1.92-1.82(\mathrm{~m}$, $2 \mathrm{H}), 1.74(\mathrm{~s}, 12 \mathrm{H}), 1,69-1.52(\mathrm{~m}, 4 \mathrm{H}), 1.42-1.35(\mathrm{~m}, 2 \mathrm{H})$, 1.25-1.12 (m, 4H); HR ESI MS $\mathrm{m} / z$ calcd. for $\left[\mathrm{C}_{37} \mathrm{H}_{51} \mathrm{~N}_{4} \mathrm{O}_{7} \mathrm{~S}_{2}\right]^{-}:$: 727.3194, found: 727.3191 .

Tz-Cy3 22. Сy3 amido hexylamine $20(59 \mathrm{mg}, 0.081 \mathrm{mmol})$ was dissolved in DMSO/pyridine 9/1 (5 mL). Tz succinimidyl ester $21^{30}$ (61 mg, $\left.0.162 \mathrm{mmol}\right)$ and $\operatorname{EtN}(i \operatorname{Pr})_{2}(14 \mu \mathrm{L})$ were added. The solution was stirred overnight, and the product was precipitated by addition of ethyl acetate $(60 \mathrm{~mL})$, collected by centrifugation, and washed with ethyl acetate $(20 \mathrm{~mL})$. The solid was dissolved in water $(7 \mathrm{~mL})$ and purified by RP HPLC to give the triethylammonium salt of $22(59 \mathrm{mg}, 68 \%)$ as a violet powder. ${ }^{1} \mathrm{H} \mathrm{NMR}\left(400 \mathrm{MHz}, \mathrm{MeOH} d_{4}\right): \delta(\mathrm{ppm})=9.11(\mathrm{~d}, J=$ $4.9 \mathrm{~Hz}, 2 \mathrm{H}), 8.69(\mathrm{~d}, J=8.3 \mathrm{~Hz}, 2 \mathrm{H}), 8.52(\mathrm{t}, J=13.5 \mathrm{~Hz}, 1 \mathrm{H})$, $8.07(\mathrm{~d}, J=8.4 \mathrm{~Hz}, 2 \mathrm{H}), 8.00-7.82(\mathrm{~m}, 6 \mathrm{H}), 7.77(\mathrm{t}, J=4.9 \mathrm{~Hz}$, $1 \mathrm{H}), 7.43-7.36(\mathrm{~m}, 2 \mathrm{H}), 6.53(\mathrm{t}, J=13.5 \mathrm{~Hz}, 2 \mathrm{H}), 4.32-4.10$ $(\mathrm{m}, 5 \mathrm{H}), 3.40(\mathrm{t}, J=7.2 \mathrm{~Hz}, 2 \mathrm{H}), 3.18-3.08(\mathrm{~m}, 2 \mathrm{H}), 2.25-2.15$ (m, 2H), 1.91-1.36 (m, overlapping signals, $28 \mathrm{H})$; HR ESI MS $m / z$ calcd. for $\left[\mathrm{C}_{50} \mathrm{H}_{57} \mathrm{~N}_{10} \mathrm{O}_{8} \mathrm{~S}_{2}\right]^{-}: 989.3808$, found: 989.3800 .

Cell Growth Conditions. HEK 293T cells were grown in Dulbecco's Modified Essential Medium (DMEM) supplemented with 5\% FBS, 100 units $\mathrm{mL}^{-1}$ penicillin, and $100 \mu \mathrm{g} \mathrm{mL}^{-1}$ streptomycin. All cells were incubated in a $5 \%$ carbon dioxide, water saturated incubator at $37^{\circ} \mathrm{C}$.

Fluorescence Microscopy with Tz-Biotin. HEK 293T cells $\left(6500-7500\right.$ cells $\left./ \mathrm{cm}^{2}\right)$ were seeded in 8 well ibiTreat $\mu$ Slides (ibidi) and allowed to attach for $12 \mathrm{~h}$. Cells were then incubated with $100 \mu \mathrm{M} \mathrm{Ac}_{4} \mathrm{ManNCyoc} 13$ for $48 \mathrm{~h}$. No sugar was added as negative control. Cells were washed two times with phosphate buffered saline (PBS) and then treated with Tzbiotin $17(25 \mu \mathrm{M})$ for $15 \mathrm{~min}$ at $37^{\circ} \mathrm{C}$. After two washes with PBS, cells were incubated with AlexaFluor647 labeled streptavi $\operatorname{din}\left(6.6 \mu \mathrm{g} \mathrm{mL}^{-1}\right)$ and Hoechst $33342\left(10 \mu \mathrm{g} \mathrm{mL}^{-1}\right)$ for $20 \mathrm{~min}$ at room temperature in the dark. Cells were washed twice with PBS and DMEM was added for microscopy. A Zeiss LSM 510 Meta equipped with a $40 \times 1.3$ NA Plan Neofluar oil DIC immersion objective was employed for imaging. Analysis of the obtained data was performed using ImageJ software version 1.45 s.

Fluorescence Microscopy with Tz-Cy3. HEK 293T cells $\left(6500-7500\right.$ cells $\left./ \mathrm{cm}^{2}\right)$ were seeded in 8 well ibiTreat $\mu$ Slides (ibidi) and allowed to attach for $12 \mathrm{~h}$. Cells were then incubated with $100 \mu \mathrm{M} \mathrm{Ac}_{4}$ ManNCyoc 13 for $48 \mathrm{~h}$. No sugar was added as negative control. Cells were washed two times with PBS and then treated with $\mathrm{Tz}$ Cy3 $22(25 \mu \mathrm{M})$ for $5-15 \mathrm{~min}$ at $37{ }^{\circ} \mathrm{C}$. Cells were washed twice with PBS and nuclei were stained with Hoechst $33342\left(10 \mu \mathrm{g} \mathrm{mL}^{-1}\right)$ for $20 \mathrm{~min}$ at room temperature in the dark. Cells were washed twice with PBS, and DMEM was added for microscopy. Microscopy was performed as described above.

Fluorescence Microscopy with Tz-Cy3 for Dual Labeling. HEK $293 \mathrm{~T}$ cells $\left(7500\right.$ cells $\left./ \mathrm{cm}^{2}\right)$ were seeded in 8 well ibiTreat $\mu$ Slides (ibidi) and allowed to attach for $12 \mathrm{~h}$. Cells were

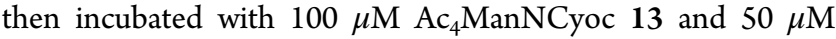
$\mathrm{Ac}_{4} \mathrm{GlcNAz} 23$ for $48 \mathrm{~h}$. No sugar or only one sugar was added as negative control. Cells were washed two times with PBS and then treated with $\mathrm{Tz}$ Cy3 $22(25 \mu \mathrm{M})$ and DIBO $48824(50 \mu \mathrm{M})$ for 15 min at $37^{\circ} \mathrm{C}$. Cells were washed twice with PBS and nuclei were stained with Hoechst $33342\left(10 \mu \mathrm{g} \mathrm{mL}^{-1}\right)$ for $20 \mathrm{~min}$ at room temperature in the dark. Cells were washed twice with PBS, and DMEM was added for microscopy. Microscopy was performed as described above.

Kinetic Measurements. For kinetic studies, $\mathrm{Ac}_{4} \mathrm{ManNCyoc}$ 13 was first deacetylated with $\mathrm{MeOH} / \mathrm{EtNMe}_{2} 5 / 1$ to give ManNCyoc 14. Stock solutions of Tz PEG $15^{21}$ and ManNCyoc 14 were made in acetate buffer $\left(\mathrm{pH} 4.8,20{ }^{\circ} \mathrm{C}\right)$ and mixed in a quartz cuvette for final concentrations of $1 \mathrm{mM} \mathrm{Tz}$ PEG 15 and 10, 13.3, and $16.6 \mathrm{mM}$, respectively, ManNCyoc 14. The reaction was monitored by the decreasing absorption of the tetrazine at $522 \mathrm{~nm}$. Pseudo first order rate constants were determined for every concentration of ManNCyoc 14 by plotting $\ln \left(A_{0} / A_{\mathrm{t}}\right)$ versus time. For the determination of $A_{0}$, a $1 \mathrm{mM}$ solution of only Tz PEG 15 was used. $A_{\mathrm{t}}$ is the absorption of the reaction mixture at time point $t$. Analysis by linear regression provided pseudo first order rate constants. Second order rate constants were determined by plotting the pseudo first order rate constants versus the corresponding ManNCyoc concen tration, followed by linear regression. All measurements were carried out in triplicate. Sufficient stability of Tz PEG 15 was verified by measuring the absorption at $522 \mathrm{~nm}$ of a solution of Tz PEG 15 in acetate buffer ${ }^{21}$ and PBS (Figure S2). Product formation was confirmed by RP HPLC and ESI MS analysis (Figure S3).

\section{RESULTS AND DISCUSSION}

Synthesis of $\mathrm{Ac}_{4}$ ManNCyoc 13. $\mathrm{Ac}_{4}$ ManNCyoc 13 with a methylcyclopropene attached as a carbamate was a promising dienophile modified sugar that was expected to have an increased reaction rate in DAinv reactions compared to previously described mannosamine derivatives. Starting from silyl protected methylcyclopropene $\mathbf{8}^{26,28}$ we first synthesized activated carbonate 11 in two steps (Scheme 1). Since methylcyclopro penyl methanol 9 is prone to polymerization upon concen tration, ${ }^{26}$ we carried out the deprotection and activation step as a one pot reaction. Removal of the trimethylsilyl group of $\mathbf{8}$ was achieved with tetra $n$ butylammonium fluoride. Subsequent addition of $p$ nitrophenyl chloroformate 10 and pyridine yielded 11 in $83 \%$ yield over two steps. Carbonate 11 was then coupled to the amino group of mannosamine that was obtained by neutralization of mannosamine hydrochloride $(12)$ with sodium methoxide. Subsequent acetylation gave $\mathrm{Ac}_{4} \mathrm{ManNCyoc} 13$.

Kinetic Studies. To determine the performance of the labeled mannosamine derivative in DAinv reactions, sugar 13 was deacetylated using $N, N$ dimethylethylamine in methanol yield ing ManNCyoc 14. Within the cell, that process is performed by nonspecific esterases. Deprotection also ensured water solubility 
Scheme 1. Synthesis of $\mathrm{Ac}_{4}$ ManNCyoc 13

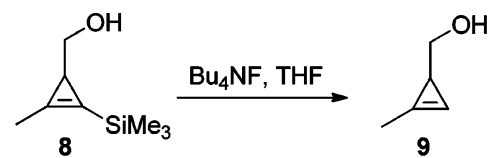<smiles>CC1CC1COC(=O)Oc1ccc([N+](=O)[O-])cc1</smiles>

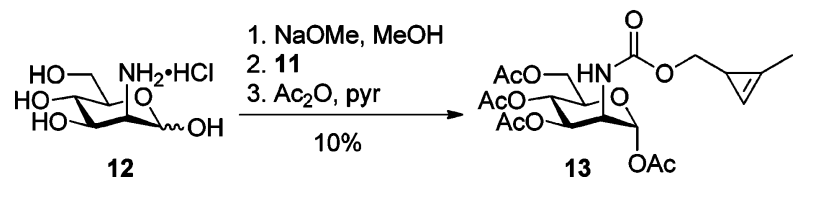

Scheme 2. Reaction of ManNCyoc 14 with Tz PEG 15 to Determine Rate Constants
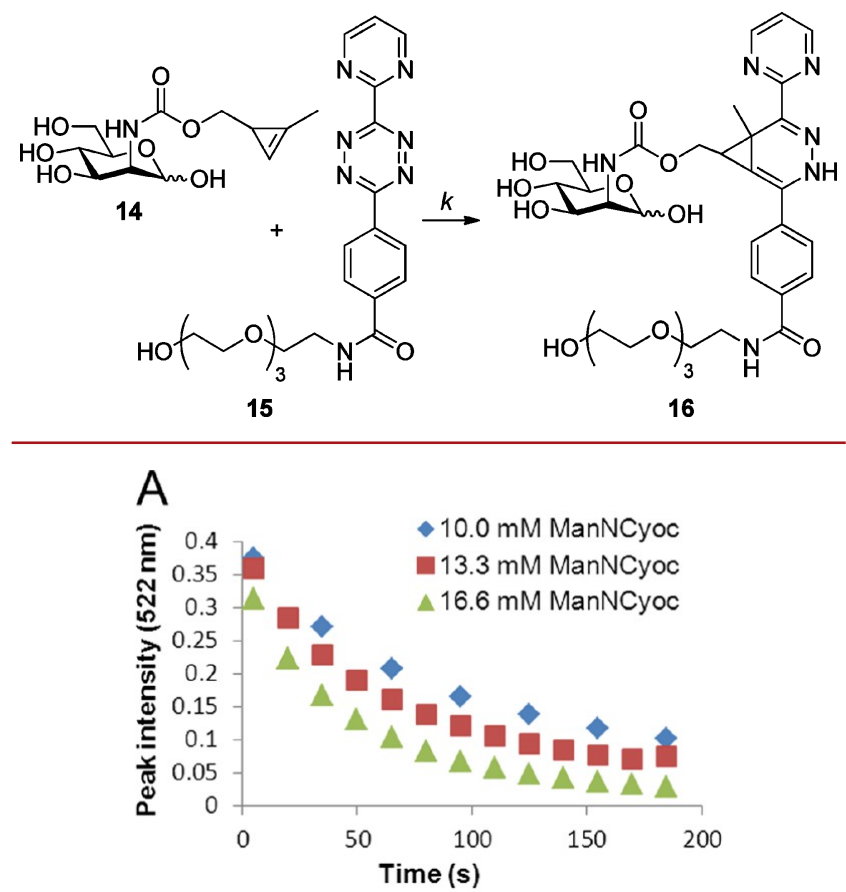

B

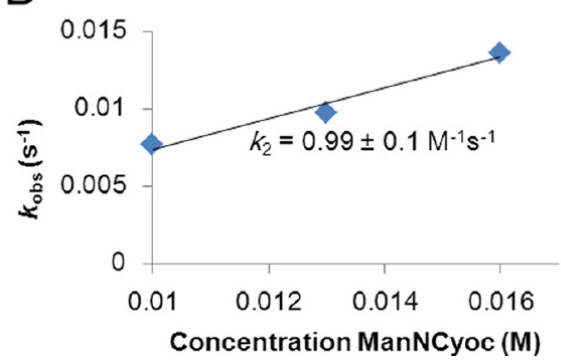

Figure 1. (A) Decrease of tetrazine absorbance at $522 \mathrm{~nm}$ over time for the reaction of Tz PEG $15(1 \mathrm{mM})$ with ManNCyoc 14 (10 mM, 13.3 $\mathrm{mM}, 16.6 \mathrm{mM}$ ) and (B) resulting second order rate constant $k$.

for the following experiments (Scheme 2). In acetate puffer $(\mathrm{pH}$ 4.7, $20{ }^{\circ} \mathrm{C}$ ), tetrazine tri(ethylene glycol) conjugate $15(\mathrm{Tz}$ $\mathrm{PEG})^{21}$ was allowed to react with an excess of ManNCyoc 14,
Chart 2. Structure of $\mathrm{Tz}-$ Biotin 17<smiles>CC(C)(CCOC(C)(C)CCNC(=O)c1ccc(-c2nnc(-c3ncccn3)nn2)cc1)NC(=O)CCCC[C@H]1SCC2NC(=O)NC21</smiles>
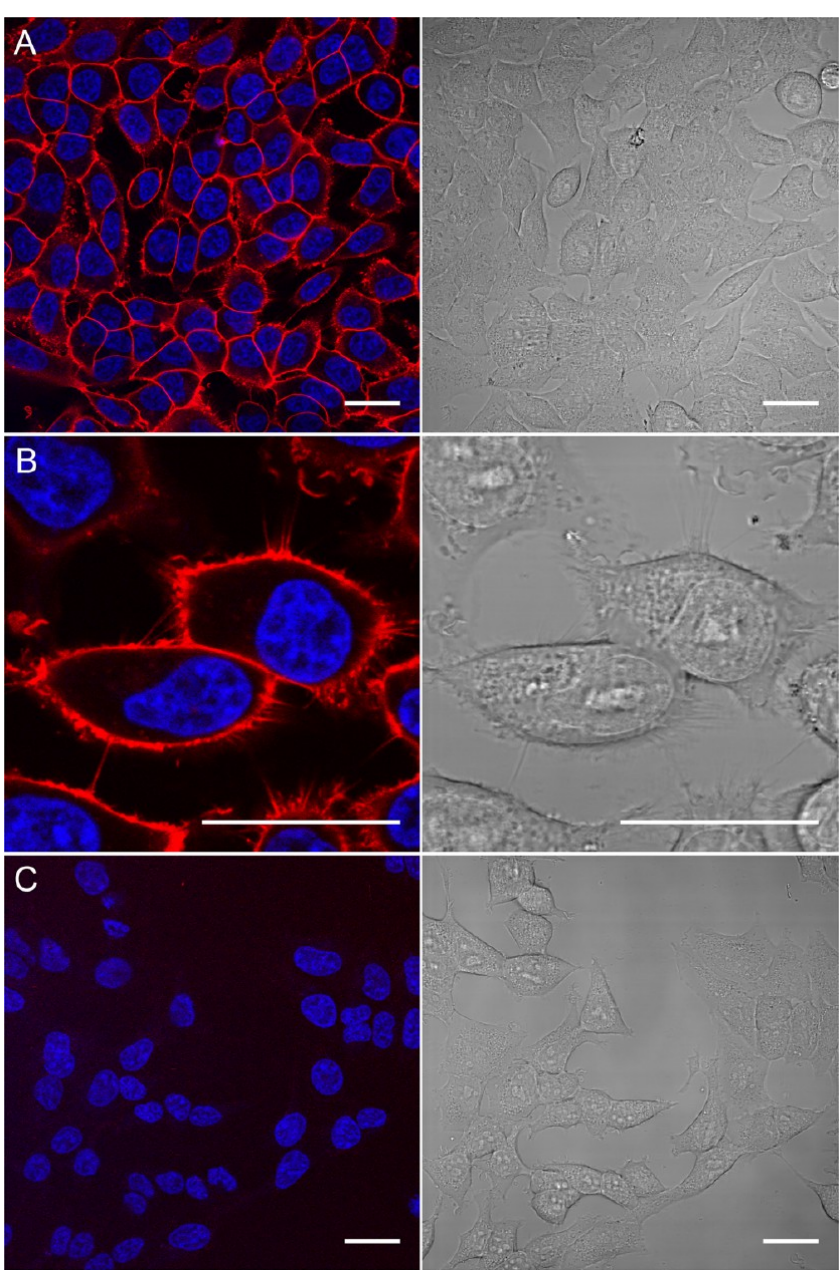

Figure 2. HEK 293T cells grown with $100 \mu \mathrm{M} \mathrm{Ac}_{4} \mathrm{ManNCyoc} 13$ (A, B) or without addition of $13(\mathrm{C})$ for $48 \mathrm{~h}$ and incubated with $\mathrm{Tz}$-biotin 17 $\left(25 \mu \mathrm{M}, 15 \mathrm{~min}, 37^{\circ} \mathrm{C}\right)$ followed by incubation with streptavidinAlexaFluor647. Nuclei were stained with Hoechst33342. Scale bar: 30 $\mu \mathrm{m}$.

and pseudo first order rate constants were determined measur ing the decrease of the absorption of $\mathbf{1 5}$ at $\lambda_{\max }=522 \mathrm{~nm}$ (Figure $1 \mathrm{~A})$. From these values the second order rate constant $k$ of dienophile 14 was determined to be $0.99 \pm 0.1 \mathrm{M}^{-1} \mathrm{~s}^{-1}$ (Figure 1B). Formation of the ligation product 16 was verified by LC MS (Figure S3).

Labeling Metabolized ManNCyoc with Tz-Biotin/ Streptavidin-AlexaFluor647 (two-step labeling). To monitor metabolic incorporation of $\mathrm{Ac}_{4} \mathrm{ManNCyoc} 13$ into 
Scheme 3. Synthesis of Tz Cy3 22

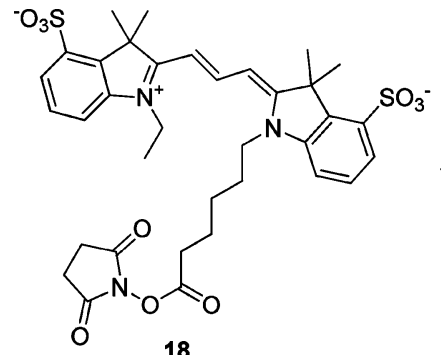

18

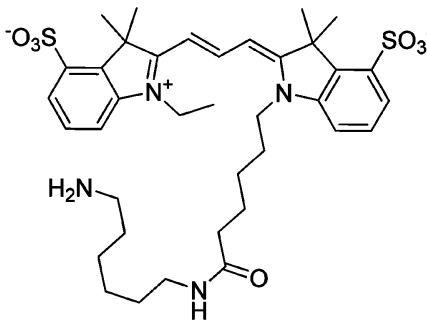

20
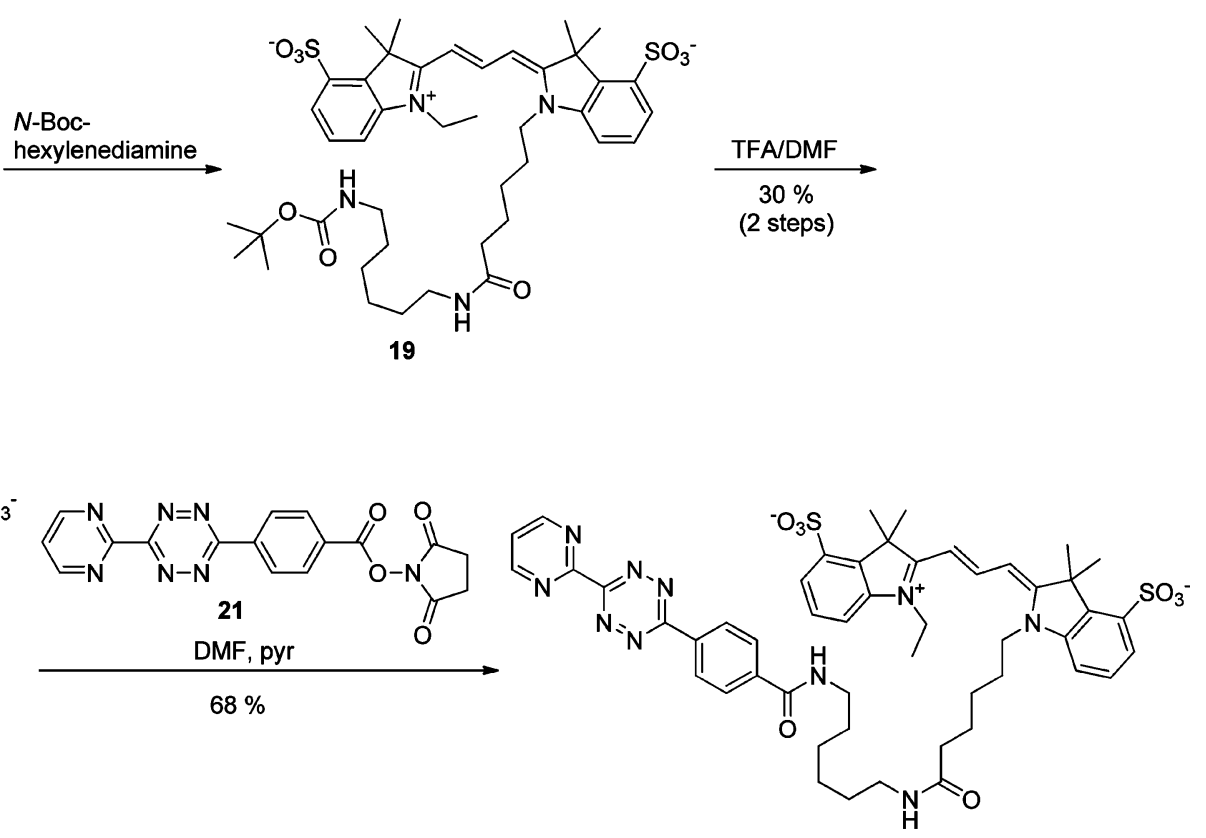

22 (Tz-Cy3)
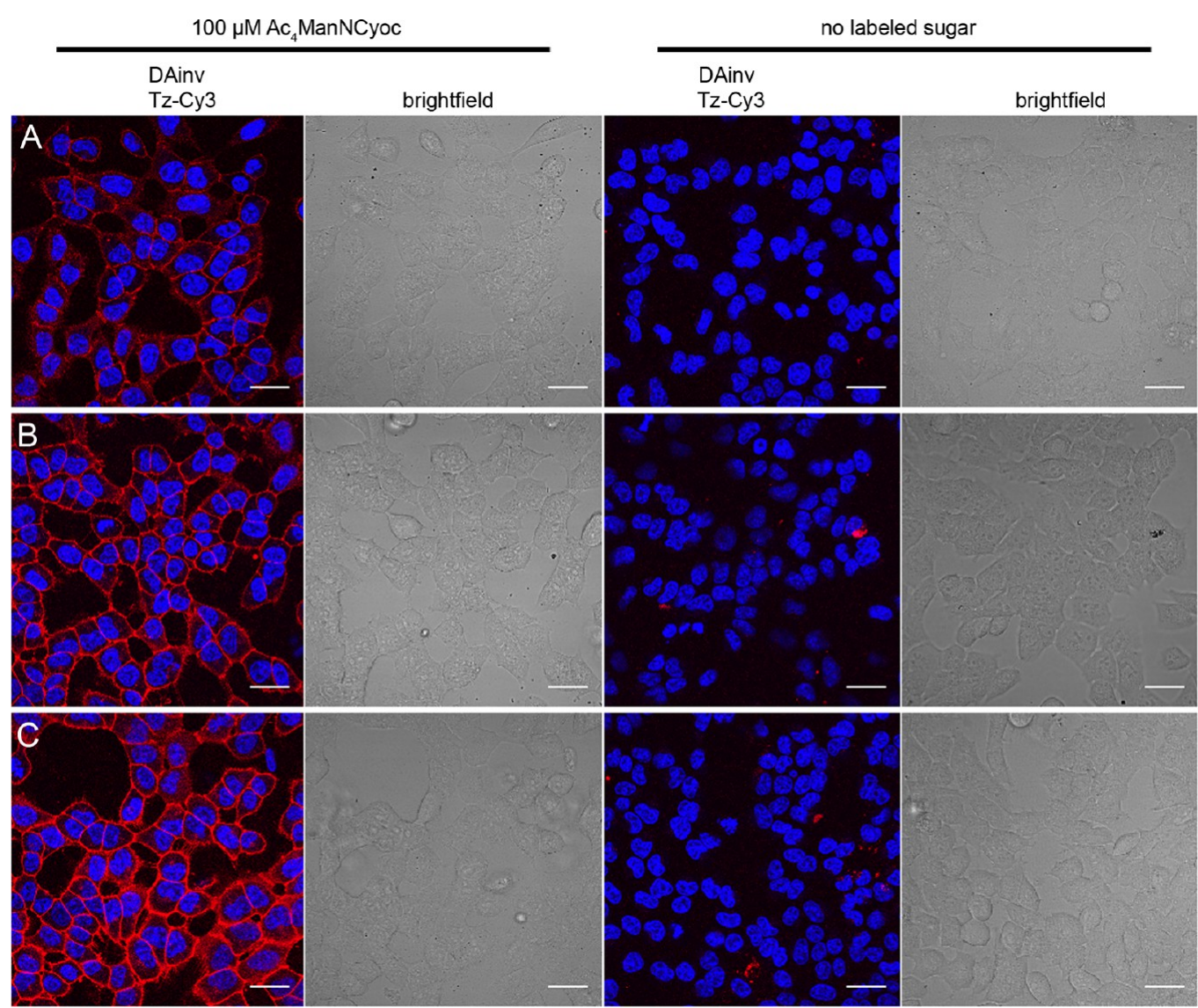

Figure 3. HEK 293T cells were grown with $100 \mu \mathrm{M} \mathrm{Ac}_{4} \mathrm{ManNCyoc} 13$ (left) or without labeled sugar (right) for $48 \mathrm{~h}$, followed by incubation with 25 $\mu \mathrm{M} \mathrm{Tz}$ Cy3 22 at $37^{\circ} \mathrm{C}$ for (A) $5 \mathrm{~min},(\mathrm{~B}) 10 \mathrm{~min}$, and (C) $15 \mathrm{~min}$. Nuclei were stained with Hoechst 33342 . Scale bar: $30 \mu \mathrm{m}$.

glycoconjugates, HEK 293T cells were grown in the presence of 13 for two days, reacted with Tz-biotin 17 (Chart 2), and then labeled with streptavidin-AlexaFluor647. Confocal laser scan ning microscopy showed a distinct labeling of the cell membrane of cells that had been cultivated with $\mathrm{Ac}_{4} \mathrm{ManNCyoc} \mathbf{1 3}$ (Figure 2A,B). The negative control, in which cells had not been treated with sugar 13, did not show any membrane staining (Figure 2C). This confirms that $\mathrm{Ac}_{4} \mathrm{ManNCyoc}$ can be employed to label 
Scheme 4. Strategy for Dual Labeling with Two Different Metabolically Incorporated Monosaccharides and a One Step Labeling Procedure

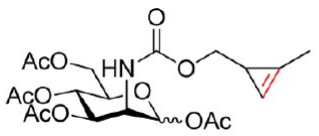

13

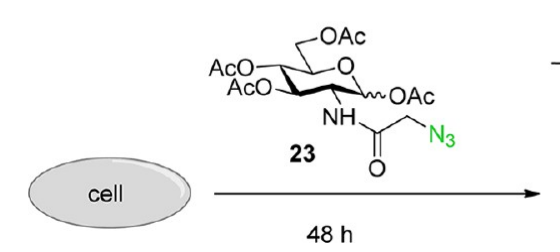

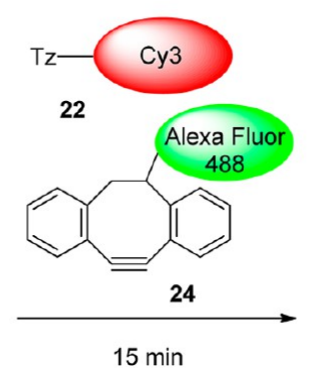

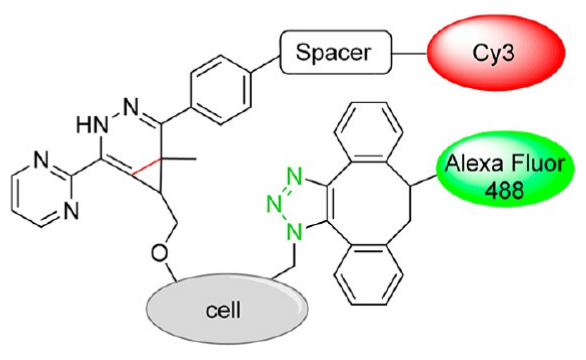

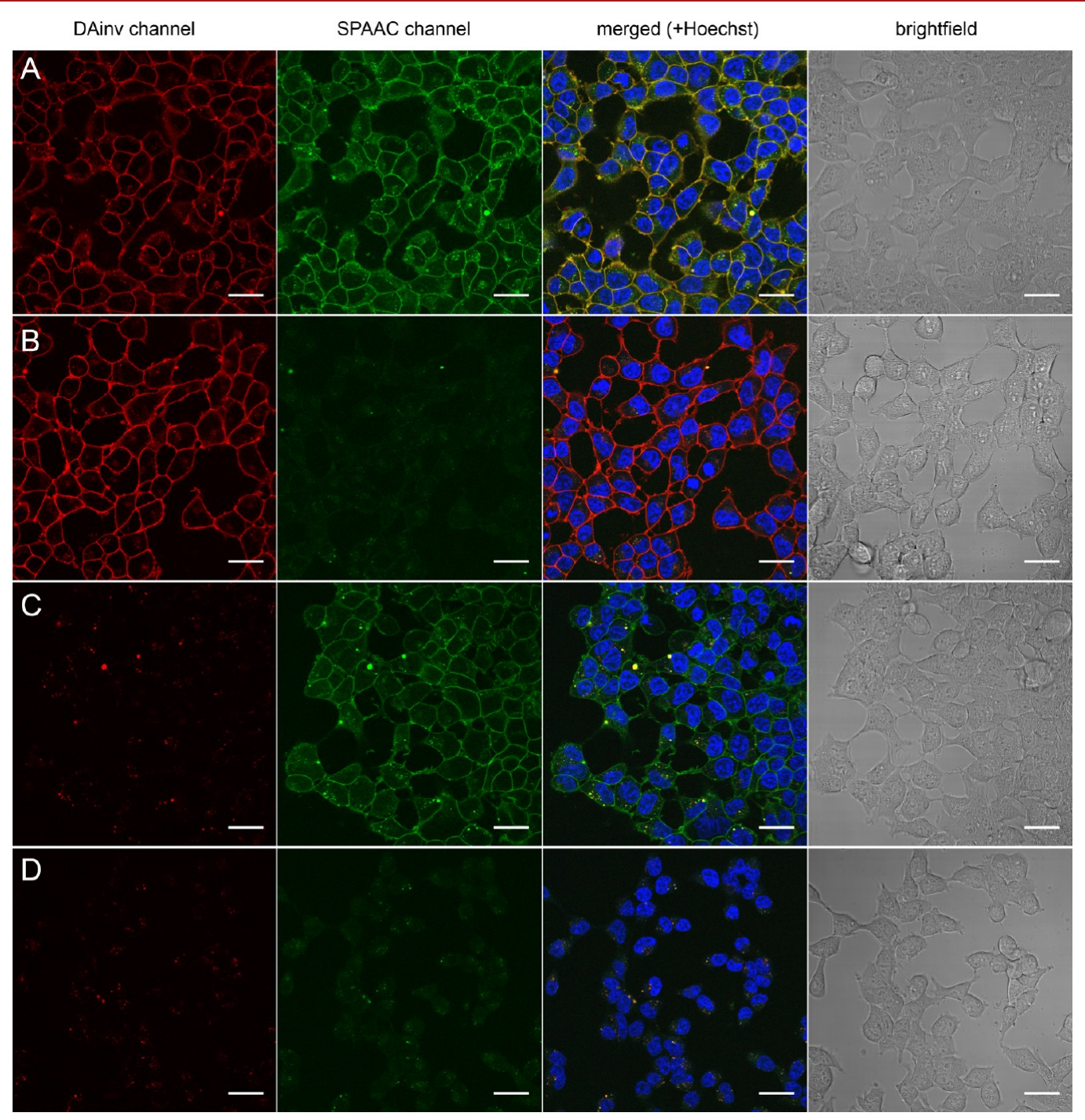

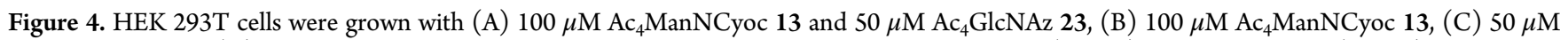
$\mathrm{Ac}_{4}$ GlcNAz 23, and (D) without addition of non natural sugar for $48 \mathrm{~h}$ and incubated with Tz Cy3 $22(25 \mu \mathrm{M})$ and DIBO $48824(20 \mu \mathrm{M})$ for 15 min at $37^{\circ} \mathrm{C}$. Nuclei were stained with Hoechst 33342 . Scale bar: $30 \mu \mathrm{m}$.

glycoconjugates. Looking at the cells with higher magnification (Figure 2B), the staining allows detailed detection of membrane structures. In comparison to the DAinv reaction of terminal alkenes, we could significantly reduce the concentration of $\mathrm{Tz}-$ biotin 17 from $1 \mathrm{mM}$ to $25 \mu \mathrm{M}$ and the time of incubation with Tz-biotin 17 from $6 \mathrm{~h}$ to $15 \mathrm{~min}$ by using $\mathrm{Ac}_{4}$ ManNCyoc 13.

Synthesis of Tz-Cy3 (22) for a One-Step Labeling Strategy. While we could reduce the incubation time and concentration of $\mathrm{Tz}$-biotin in comparison to our labeling protocol for terminal alkenes, a one step labeling is even more elegant. This requires the use of a dye coupled tetrazine. Tz Cy3 22 was chosen to be a suitable tetrazine-dye conjugate as the absorption/emission wavelengths of $\mathrm{Cy} 3$ can be combined with those of AlexaFluor488 labeled probes. In addition, Tz Cy3 22 is, owing to the sulfo groups, highly water soluble resulting in low background staining. Furthermore, using sulfo Cy3 rather 
than Cy3 facilitated chemical purification of 22. Commercially available sulfo Cy3 succinimidyl ester 18 was reacted with $\mathrm{N}$ Boc hexylenediamine, and the Boc protecting group of 19 was removed with trifluoroacetic acid (TFA) in DMF to give 20. Finally, the free amine was reacted with $\mathrm{Tz}$ succinimidyl ester $\mathbf{2 1} 1^{30}$ to yield Tz Cy3 22 in $68 \%$ yield (Scheme 3 ).

MOE and Subsequent Labeling with Tz-Cy3 22 (onestep labeling). To test the suitability of the novel $\mathrm{Tz} C \mathrm{Cy} 322$, HEK 293T cells were cultured in the presence of $\mathrm{Ac}_{4} \mathrm{ManNCyoc}$ 13. Subsequently, the cells were incubated with Tz Cy3 22. Confocal laser scanning microscopy showed a clear labeling of the cell membrane already after $5 \mathrm{~min}$ of incubation with $\mathrm{Tz} \mathrm{Cy} 3$ (Figure 3A, left). Prolonging the incubation time to $10 \mathrm{~min}$ (Figure 3B, left) increased the intensity significantly, while an even longer incubation time (15 min, Figure 3C, left) only incrementally increased the intensity. Control experiments, in which cells were cultured in the absence of labeled sugar but otherwise treated in the same way, did not show any membrane staining (Figure 3, right).

Dual Labeling with $\mathrm{Ac}_{4}$ ManNCyoc 13 and $\mathrm{Ac}_{4}$ GlcNAz 23. Current interest in the area of MOE has turned to dual labeling strategies employing two different metabolically incorporated monosaccharides, for example, ManNAc and $N$ acetylglucosamine (GlcNAc) derivatives in the same experiment. As the DAinv reaction can be orthogonal to the strain promoted azide-alkyne cycloaddition (SPAAC), we combined these two ligation reactions for dual labeling. As second sugar derivative, we chose peracetylated $N$ azidoacetylglucosamine ( $\left.\mathrm{Ac}_{4} \mathrm{GlcNAz}\right) 23$ that has been reported to be incorporated into different glycoconjugates $^{31}$ and undergoes rapid SPAAC with DIBO 48824 (Scheme 4). Since both the DAinv reaction between $\mathrm{Ac}_{4}$ ManNCyoc 13 and $\mathrm{Tz} \mathrm{Cy} 322$ and SPAAC between $\mathrm{Ac}_{4} \mathrm{GlcNAz} 23$ and DIBO 48824 occur within minutes, labeling of both sugars could be carried out simultaneously in a single step.

HEK 293 T cells were grown in the presence of both sugars (13 and 23) for $48 \mathrm{~h}$ and subsequently stained by incubation with a mixture of $\mathrm{Tz}$ Cy3 22 and DIBO 48824 for $15 \mathrm{~min}$ and then investigated by confocal fluorescence microscopy (Figure 4A). In control experiments, cells were grown with only one (Figures $4 B, C$ ) or no sugar (Figure 4D). When both sugars were fed, a clear membrane staining was detected in both the DAinv channel (red) and the SPAAC channel (green) indicating that both sugars have been incorporated into membrane glycoconjugates and could be stained. If only $\mathrm{Ac}_{4}$ ManNCyoc 13 was fed, a significant membrane staining is only visible in the DAinv channel (Figure 4B), while cells that had been fed with $\mathrm{Ac}_{4} \mathrm{GlcNAz} 23$ alone only show membrane staining in the SPAAC channel (Figure 4C). When no sugar was present, no membrane staining was obtained (Figure 4D). These experi ments show that the DAinv reaction of $\mathrm{Ac}_{4}$ ManNCyoc 13 is orthogonal to the SPAAC of $\mathrm{Ac}_{4} \mathrm{GlcNAz} 23$ and both reactions can be performed at the same time, facilitating the labeling reaction significantly. Dual Labeling was also successfully performed using peracetylated $N$ azidoacetylgalactosamine $\left(\mathrm{Ac}_{4}\right.$ GalNAz 25) in combination with $\mathrm{Ac}_{4}$ ManNCyoc 13 (Figure S4). Furthermore, we could show that also the combination of SPAAC and DAinv reactions using Tz biotin 17 and subsequent labeling with streptavidin AlexaFluor647 is possible and results in clear staining of membrane glycoproteins (Figure S5).

\section{CONCLUSION}

In summary, we have developed a fast reacting mannosamine derivative $\left(\mathrm{Ac}_{4} \mathrm{ManNCyoc} \mathrm{13}\right)$, bearing a carbamate linked methylcyclopropene tag that is small enough to be accepted by the cell's metabolism and at the same time highly reactive in the inverse electron demand Diels-Alder reaction. We demonstra ted that a labeling time of as low as $5 \mathrm{~min}$ is sufficient for a distinct membrane staining, making $\mathrm{Ac}_{4}$ ManNCyoc 13 a very valuable mannosamine derivative for MOE experiments. Furthermore, we introduced $\mathrm{Tz} \mathrm{Cy} 322$, a novel tetrazine-dye conjugate that not only allows one step fluorescent labeling of alkenes, but also stands out by its high water solubility leading to remarkably low background staining. Finally, we reported - to the best of our knowledge - the first procedure in which dual sugar labeling is achieved by simultaneous DAinv and SPAAC reactions in a single step.

\section{AUTHOR INFORMATION}

\section{Corresponding Author}

*Phone: +49 7531 884572. Fax: +49 7531 884573. E mail: mail@valentin wittmann.de.

\section{Notes}

The authors declare no competing financial interest.

\section{ACKNOWLEDGMENTS}

This work was supported by the Deutsche Forschungsgemein schaft (SFB 969 and SPP 1623), the University of Konstanz, and the Konstanz Research School Chemical Biology. We thank Prof. Werner Reutter for fruitful discussions and the Bioimaging Center of the University of Konstanz for providing the fluorescence microscopy instrumentation.

\section{REFERENCES}

(1) Keppler, O. T., Horstkorte, R., Pawlita, M., Schmidt, C., and Reutter, W. (2001) Biochemical engineering of the $\mathrm{N}$ acyl side chain of sialic acid: biological implications. Glycobiology 11, 11R-18R.

(2) Dube, D. H., and Bertozzi, C. R. (2003) Metabolic oligosaccharide engineering as a tool for glycobiology. Curr. Opin. Chem. Biol. 7, 616625.

(3) Prescher, J. A., and Bertozzi, C. R. (2006) Chemical technologies for probing glycans. Cell 126, 851-854.

(4) Du, J., Meledeo, M. A., Wang, Z., Khanna, H. S., Paruchuri, V. D. P., and Yarema, K. J. (2009) Metabolic glycoengineering: Sialic acid and beyond. Glycobiology 19, 1382-1401.

(5) Sletten, E. M., and Bertozzi, C. R. (2009) Bioorthogonal chemistry: fishing for selectivity in a sea of functionality. Angew. Chem., Int. Ed. 48 , 6974-6998.

(6) Hackenberger, C. P. R., and Schwarzer, D. (2008) Chemoselective ligation and modification strategies for peptides and proteins. Angew. Chem., Int. Ed. 47, 10182-10228.

(7) Mahal, L. K., Yarema, K. J., and Bertozzi, C. R. (1997) Engineering chemical reactivity on cell surfaces through oligosaccharide biosynthesis. Science 276, 10030-10074.

(8) Saxon, E., and Bertozzi, C. R. (2000) Cell surface engineering by a modified Staudinger reaction. Science 287, 2007-2010.

(9) Tornøe, C. W., Christensen, C., and Meldal, M. (2002) Peptidotriazoles on solid phase: $[1,2,3]$ triazoles by regiospecific 
copper(I) catalyzed 1,3 dipolar cycloadditions of terminal alkynes to azides. J. Org. Chem. 67, 3057-3064.

(10) Rostovtsev, V. V., Green, L. G., Fokin, V. V., and Sharpless, K. B. (2002) A stepwise Huisgen cycloaddition process: copper(I) catalyzed regioselective "ligation" of azides and terminal alkynes. Angew. Chem., Int. Ed. 41, 2596-2599.

(11) Agard, N. J., Prescher, J. A., and Bertozzi, C. R. (2004) A strain promoted $[3+2]$ azide alkyne cycloaddition for covalent modification of biomolecules in living systems. J. Am. Chem. Soc. 126, 15046-15047. (12) Ning, X., Guo, J., Wolfert, M. A., and Boons, G. J. (2008) Visualizing metabolically labeled glycoconjugates of living cells by copper free and fast Huisgen cycloadditions. Angew. Chem., Int. Ed. 47, $2253-2255$.

(13) Braun, K., Wiessler, M., Ehemann, V., Pipkorn, R., Spring, H., Debus, J., Didinger, B., Koch, M., Muller, G., and Waldeck, W. (2008) Treatment of glioblastoma multiforme cells with Temozolomide BioShuttle ligated by the inverse Diels Alder ligation chemistry. Drug Des. Dev. Ther. 2, 289-301.

(14) Blackman, M. L., Royzen, M., and Fox, J. M. (2008) Tetrazine ligation: fast bioconjugation based on inverse electron demand Diels Alder reactivity. J. Am. Chem. Soc. 130, 13518-13519.

(15) Devaraj, N. K., Weissleder, R., and Hilderbrand, S. A. (2008) Tetrazine based cycloadditions: application to pretargeted live cell imaging. Bioconjugate Chem. 19, 2297-2299.

(16) Knall, A. C., and Slugovc, C. (2013) Inverse electron demand Diels-Alder (iEDDA) initiated conjugation: a (high) potential click chemistry scheme. Chem. Soc. Rev. 42, 5131-5142.

(17) Šečkute, J., and Devaraj, N. K. (2013) Expanding room for tetrazine ligations in the in vivo chemistry toolbox. Curr. Opin. Chem. Biol. 17, 761-767.

(18) Jiang, X., and Wang, R. (2013) Recent developments in catalytic asymmetric inverse electron demand Diels-Alder reaction. Chem. Rev. 113, 5515-5546.

(19) Karver, M. R., Weissleder, R., and Hilderbrand, S. A. (2012) Bioorthogonal reaction pairs enable simultaneous, selective, multi target imaging. Angew. Chem., Int. Ed. 51, 920-922.

(20) Willems, L. I., Li, N., Florea, B. I., Ruben, M., van der Marel, G. A., and Overkleeft, H. S. (2012) Triple bioorthogonal ligation strategy for simultaneous labeling of multiple enzymatic activities. Angew. Chem., Int. Ed. 51, 4431-4434.

(21) Niederwieser, A., Späte, A. K., Nguyen, L. D., Jüngst, C., Reutter, W., and Wittmann, V. (2013) Two color glycan labeling of live cells by a combination of Diels Alder and click chemistry. Angew. Chem., Int. Ed. $52,4265-4268$.

(22) Cole, C. M., Yang, J., Šečkutè, J., and Devaraj, N. K. (2013) Fluorescent live cell imaging of metabolically incorporated unnatural cyclopropene mannosamine derivatives. ChemBioChem 14, 205-208.

(23) Wainman, Y. A., Neves, A. A., Stairs, S., Stoeckmann, H., Ireland Zecchini, H., Brindle, K. M., and Leeper, F. J. (2013) Dual sugar imaging using isonitrile and azido based click chemistries. Org. Biomol. Chem. 11, $7297-7300$

(24) Sauer, J., Heldmann, D. K., Hetzenegger, J., Krauthan, J., Sichert, H., and Schuster, J. (1998) 1,2,4,5 Tetrazine: synthesis and reactivity in [4 + 2] cycloadditions. Eur. J. Org. Chem. 1998, 2885-2896.

(25) Stairs, S., Neves, A. A., Stöckmann, H., Wainman, Y. A., Ireland Zecchini, H., Brindle, K. M., and Leeper, F. J. (2013) Metabolic glycan imaging by isonitrile-tetrazine click chemistry. ChemBioChem 14, 1063-1067.

(26) Patterson, D. M., Nazarova, L. A., Xie, B., Kamber, D. N., and Prescher, J. A. (2012) Functionalized cyclopropenes as bioorthogonal chemical reporters. J. Am. Chem. Soc. 134, 18638-18643.

(27) Stöckmann, H., Neves, A. A., Stairs, S., Brindle, K. M., and Leeper, F. J. (2011) Exploring isonitrile based click chemistry for ligation with biomolecules. Org. Biomol. Chem. 9, 7303-7305.

(28) Yang, J., Šečkutè, J., Cole, C. M., and Devaraj, N. K. (2012) Live cell imaging of cyclopropene tags with fluorogenic tetrazine cyclo additions. Angew. Chem., Int. Ed. 51, 7476-7479.

(29) Bateman, L. A., Zaro, B. W., Chuh, K. N., and Pratt, M. R. (2013) $\mathrm{N}$ Propargyloxycarbamate monosaccharides as metabolic chemical reporters of carbohydrate salvage pathways and protein glycosylation. Chem. Commun. 49, 4328-4330.

(30) Beckmann, H. S. G., Niederwieser, A., Wiessler, M., and Wittmann, V. (2012) Preparation of carbohydrate arrays by using Diels-Alder reactions with inverse electron demand. Chem.-Eur. J. 18, $6548-6554$.

(31) Zaro, B. W., Yang, Y. Y., Hang, H. C., and Pratt, M. R. (2011) Chemical reporters for fluorescent detection and identification of $\mathrm{O}$ GlcNAc modified proteins reveal glycosylation of the ubiquitin ligase NEDD4-1. Proc. Natl. Acad. Sci. U. S. A. 108, 8146-8151. 